\title{
MVP Gene
}

National Cancer Institute

\section{Source}

National Cancer Institute. MVP Gene. NCI Thesaurus. Code C104702.

This gene plays a role in vault ribonucleoprotein complex structure. 